IJMS 16 (1), 165-184 (2009)

\title{
THE DEVELOPMENT OF AERIAL PHOTOGRAPHY APPLICATION BASED ON AERIAL IMAGES CAPTURED FROM A REMOTE CONTROL AIRPLANE
}

\author{
ZULIKHA JAMALUDIN \\ FAHKRUL ANUAR AZIZ \\ College of Arts and Sciences \\ Universiti Utara Malaysia
}

\begin{abstract}
This paper shows that we can obtain aerial scenes faster, cheaper, safer, and easier using a reasonable resolution camera and a remote control airplane ( $R C$ plane). $R C$ plane can fly low, thus able to capture aerial images from low altitude. It is shown here the method of generating a digital scene from such images. We begin with capturing aerial images for selected locations within Universiti Utara Malaysia (UUM) campus using RC plane. These images have been stitched together to create the campus scene. A few scenes were then collected to create the UUM Digital Aerial Scenes (UUM-DAS) prototype. The resulting prototype enables viewers to explore the campus virtually from a of bird's eye view, with the altitude of about 150 to 200 metres. Similar approach of obtaining DAS can be generalised for marketing strategy, farm management, map disaster locations, map landscapes, monitor construction sites and progress, advertise property, and for viewing archaeological arttifacts.
\end{abstract}

Keywords: Aerial views; digital aerial scene; remote control airplane; virtual map.

\begin{abstract}
ABSTRAK
Artikel ini menunjukkan bahawa pemandangan dari udara boleh diperoleh dengan lebih cepat, murah, selamat, dan mudah menggunakan kamera dengan peleraian sesuai dan kapal terbang kawalan jauh. Kapal terbang jenis ini boleh terbang rendah, dengan itu mampu merakam gambar dari altitud rendah. Artikel ini turut menunjukkan kaedah menjana pemandangan digital daripada rakaman gambar tersebut. Langkah dimulai dengan merakam beberapa imej di lokasi terpilih dalam kampus Universiti Utara Malaysia (UUM) menggunakan
\end{abstract}


kapal terbang kawalan jauh ini. Imej-imej ini kemudiannya di 'jahit' bersamasama untuk mencipta pemandangan kampus. Beberapa pemandangan yang dicipta digabung sekali lagi untuk mencipta prototaip pemandangan digital kampus UUM dari udara. Prototaip yang dihasilkan ini membolehkan pengguna meneroka kampus secara maya dalam bentuk 'bird's eye view', dari ketinggian 150 - 200 meter. Pendekatan yang serupa dalam mencipta pemandangan digital dari udara boleh diperluaskan untuk strategi pemasaran, pengurusan ladang, pemetaan lokasi bencana, pemetaan landskap, pemantauan tapak pembinaan, pengiklanan hartanah, dan juga untuk tinjauan artifak arkeologi.

Kata kunci: Tinjauan udara; pemandangan digital dari udara; kapal terbang kawalan jauh; peta maya.

\section{INTRODUCTION}

Remote control airplanes (RC planes) are small model aircrafts that can be controlled remotely using hand-held transmitters and receivers within the planes. The receivers control the corresponding servomechanisms that move the control surfaces based on the position of joysticks on the transmitter, which in turn maneuvers the plane. Most of the planes are powered by electric or gas. This unmanned plane was previously used for leisure purposes, but now it is used for many serious reasons including land surveying and urban management.

Aerial scene using RC planes combines flying with photography. This is made possible by the availability of cheaper high resolution portable, lightweight, miniature cameras. These characteristics make it possible for the camera to be mounted onto an RC plane, letting the plane fly even with extra burden. RC planes fly low, enabling us to capture images from a low altitude. Using RC plane with low altitude for aerial photography has certain advantages compared to traditional photography (high altitude). For instance its cost of outfit, operations, and maintenance are low whereelse the high altitude aerial photography tends to be costly. Moreover, capturing images at low altitude would produce clearer and sharper photographs due to less atmospheric haze.

\section{Aerial Photography Chronology}

The first aerial photograph was taken in 1858 by Gasper Felix Tournachon known as Nadar. It was taken from a captive balloon at an altitude of 1,200 feet over Paris (refer Figure 1).

IJMS 16 (1), 165-184 (2009) 


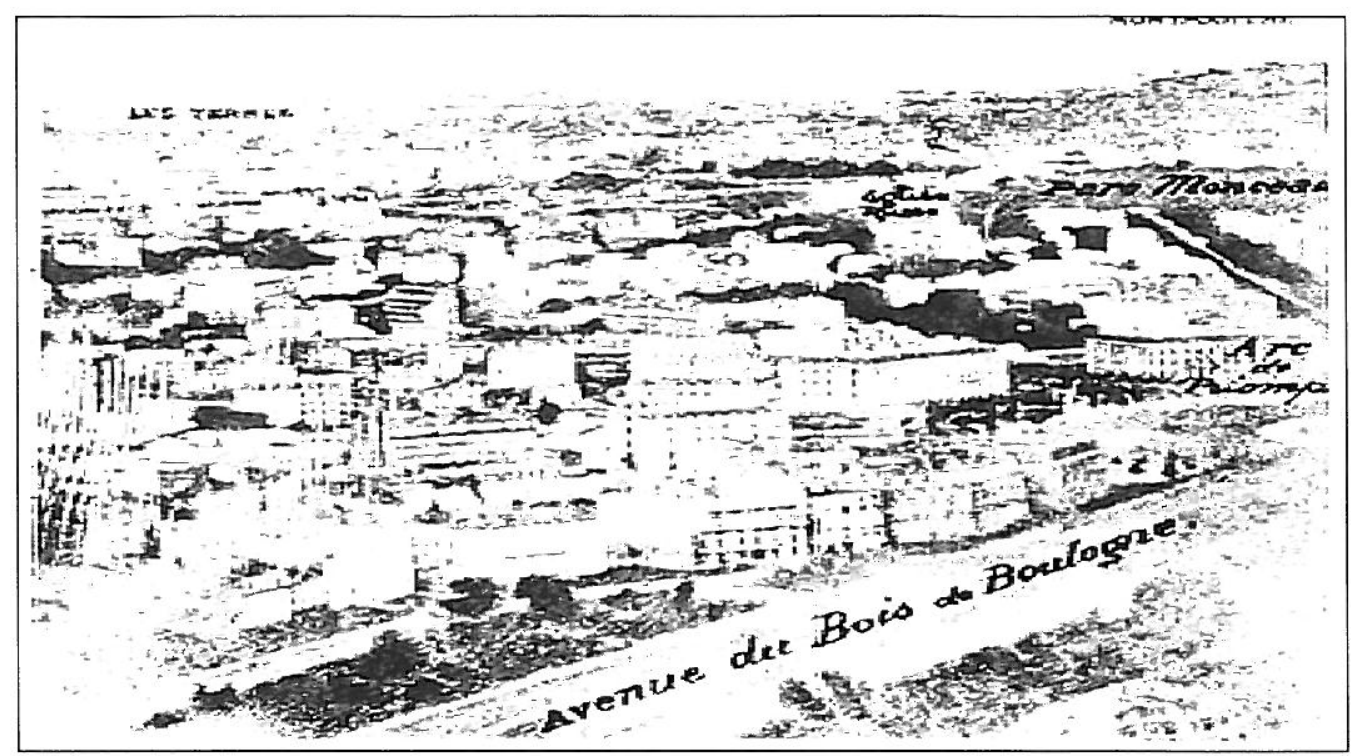

Figure 1: A copy of the first aerial photo by Nadar

(Source: http://arch.ced.berkeley.edu/kap/background/history.html)

In 1889, Arthur Batut took the first aerial photograph of Labruguiere, France using a kite. Later in 1903, pigeons were used by Bavarian Pigeon Corps to take aerial photos. A small lightweight camera was attached to a pigeon before it flew. The camera was set to automatically snap pictures every 30 seconds. At that time, this technique was considered as an innovative way of taking aerial photos compared to dangerous balloon and unstable kite (Hemphill, 2006).

In 1906, Albert Maul, took an aerial photograph using a rocket propelled by compressed air, from a height of 2,600 feet. The camera was ejected from the rocket and landed using a parachute. Later, during World War I, aerial photography became recognised as an operational military tool. Airplanes were use to take photographs of enemy territories and movements. After the war, the potential use of this technology for civilian purposes was acknowledged. It began to be used for making maps, retrieving information regarding the topography, landform, vegetation, and cultural features present on the surface of the earth. Since then, many countries have been photographing their areas on a regular basis, both for military and civilian purposes.

With technology advancement, satellites have then been used to obtain good quality photographic data. The first satellite photographs of Earth were made on 1 April 1960 by the weather satellite called TIROS-1. 
In the same year, the United States had began to collect intelligence photography of Earth using CORONA, which is a spy satellite (Figure 2). Now, there have been many satellites launched for various purposes. Some of them are used for weather forecasting, broadcasting, and inventing new technologies or discoveries.

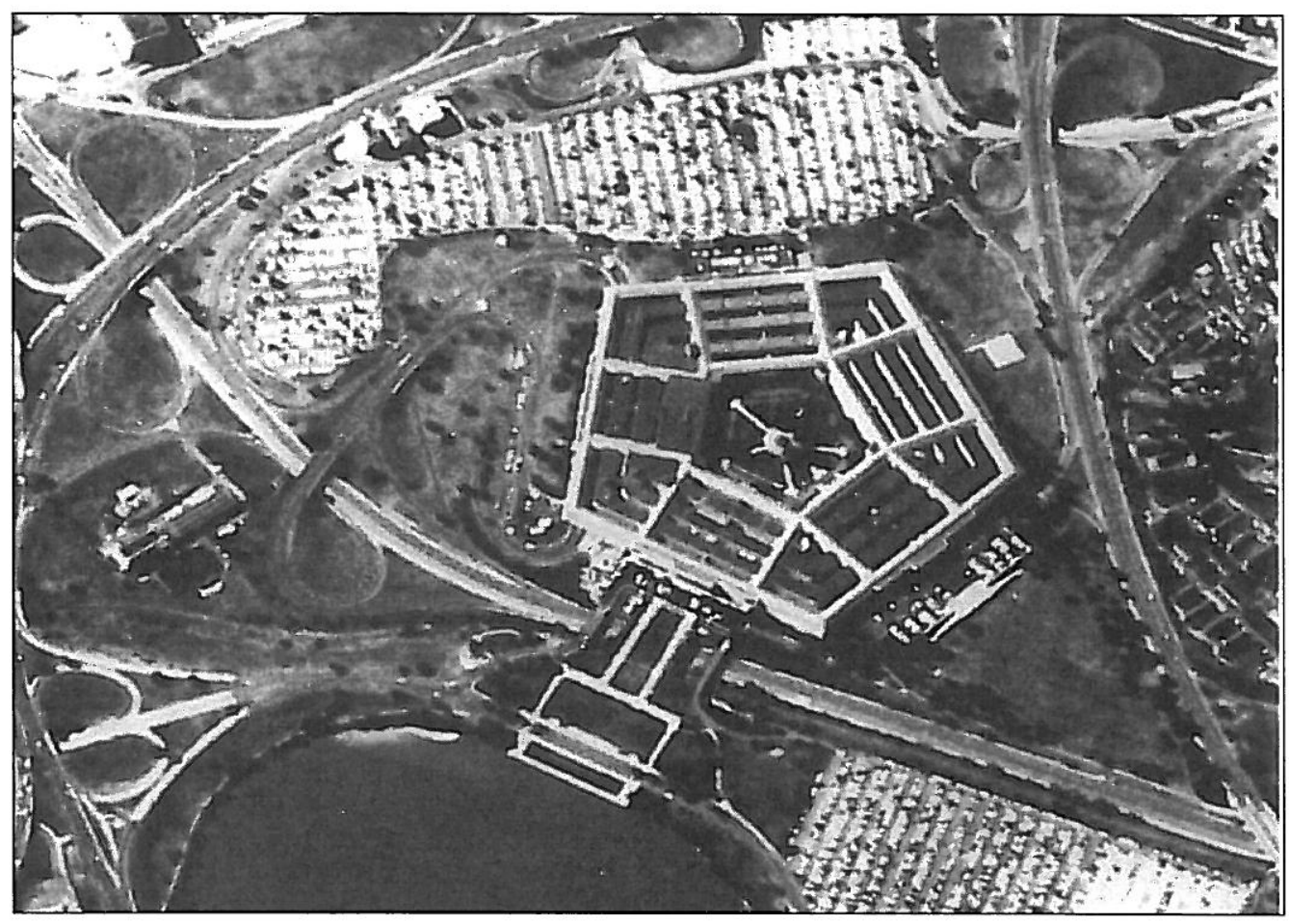

Figure 2: A copy of aerial photo taken with CORONA Satellite

(Source: http://rst.gsfc.nasa.gov/Intro/Part2_26e.html)

In 2005, another method for obtaining aerial photographs was explored. McFayden (2005) started another chapter when he used the RC plane to capture aerial images.

\section{The Benefits and Drawbacks of RC Planes}

Based on his experience, McFayden (2005) claimed that RC planes can offer significant advantages compared to traditional aerial photography. Among others, it is significantly cheap, quiet, fast, and it can fly low altitudes. Table 1 lists a comparison between RC plane and full-size manned airplane aerial photography. 
Table 1: Advantages Offered by RC Planes Aerial Photography

\begin{tabular}{ll}
\hline \multicolumn{1}{c}{ Low-Altitude RC Aerial Photography } & \multicolumn{1}{c}{$\begin{array}{c}\text { Full-Size Airplane Aerial } \\
\text { Photography }\end{array}$} \\
\hline $\begin{array}{l}\text { Lower Cost: cheaper to outfit, operate, } \\
\text { and maintain equipment }\end{array}$ & Costly \\
$\begin{array}{l}\text { Lower }\left(1-1000^{\prime}\right) \text { altitude } \\
\text { Less atmospheric haze so photos are } \\
\text { clearer and sharper }\end{array}$ & $\begin{array}{l}\text { Limited to no less than } 1000^{\prime} \text { in } \\
\text { many areas }\end{array}$ \\
$\begin{array}{l}\text { Much wider range of angles on the } \\
\text { subject }\end{array}$ & $\begin{array}{l}\text { Limited range of angles } \\
\text { Long-range telephoto lens can } \\
\text { rmaller, distortion-free lenses can be } \\
\text { red in image-distortion }\end{array}$ \\
$\begin{array}{l}\text { Quiet - property owners are not dis- } \\
\text { turbed by fly-overs }\end{array}$ & Noisy \\
$\begin{array}{l}\text { Fast - No travel to and from a traditional } \\
\text { airfield is required }\end{array}$ & Longer time to get pictures \\
\hline
\end{tabular}

A few RC plane flyer groups such as ShredAir (2005) and RCGroups.com (2006) compared RC planes and full-size airplane aerial photography. They had claimed that RC planes bore two major constrains, namely bad weather and low-lying obstacles such as electric cables. Winds above $15 \mathrm{mph}$ is damaging enough to a lightweight aircraft as compared to heavier aircrafts which are not as sensitive to wind. Thus, a full-size airplane could shoot in more varied weather. Being a low altitude plane, $\mathrm{RC}$ planes have another challenge in avoiding low-lying obstacles such as electric cables and other safety hazards. Full-size aircrafts generally fly high enough to avoid common obstacles.

Despite the disadvantages, RC planes, especially when used in aerial photography, could generate many appealing applications such as the one used for marketing strategy, farm management, mapping disaster locations, monitoring construction sites and progress, advertising property, and viewing archaeological artifacts. Obviously, this technology could assist people in many areas such as landscaping, construction, agriculture, and archeology.

\section{This Study in Brief}

One of the prime benefits of RC planes stated above is that it is cheap. Traditional aerial photography using real airplanes are expensive and

IJMS 16 (1), 165-184 (2009) 169 
tied to a certain protocol. For that reason, aerial photography by the means of RC airplanes should be learned and explored. There have been extremely limited studies on digital aerial scenes using RC airplanes in Malaysia. Thus we have come out with an innovation in obtaining digital aerial scenes, i.e. by combining images, captured using a digital camera. We then designed a prototype which provides digital aerial scenes (DAS) for selected locations within Universiti Utara Malaysia (UUM). The scenes were collected, cleaned, and combined to create the UUM DAS prototype. This prototype enables viewers to explore the campus virtually in the form of a bird's eye view, with the altitude of less than 200 metres. It could be used as tourism tool where it provides virtual maps and guide for new students, staff, and visitors.

\section{RELATED STUDIES}

There has been particularly limited studies on RC plane usage in support of research and development (R\&D). The RC plane maintains as a hobby, and used for leisure purposes. Only in year 2006 did we witness Derick's aerial photography being celebrated (Veliz, 2006) when one of Derick's photogarphs was accepted for inclusion in the Guinness Book of Records. It was a night aerial photo of the world's largest human national flag that comprised 1300 participants. Only then has the RC plane become a familiar term used as R\&D apparatus.

\section{Current Applications of Aerial Photography}

Listed below is a list of diverse applications of aerial photography ventured by Kirwan (the-lightbox, n.d.), RCGroups.com (2006), Anderson and Dickerson (n.d.), and ShredAir (2005).

Kirwan (the-lightbox, n.d.), a professional aerial photographer, had traveled around to many countries to capture aerial pictures from a light aircraft. His works had appeared in many books and publications, including The Guardian, The Rough Guides, Outdoor Photography, Digital Camera, Grand Designs, and Global Adventure. In 2000, he was named The Observer Outdoor Photographer of the Year.

While Kirwan captured images and sent them for publications, ShredAir (2005) via its website offers an aerial photography service and European model airplane brokering service on-demand. Internet surfers who are interested with their service can view samples of aerial photos from their galleries.

170 IJMS 16 (1), 165-184 (2009) 
ShredAir's work has inspired a team of RC plane devotees to build a website called RCGroups.com (2006), which is a dedicated RC plane community on the Internet. Currently there are more than 1000 members registered with RCGroups.com. Members have the ability to join public discussions, communicate with other members via private messages, respond to polls, and upload aerial photos. There are lots of aerial photos, tips, and discussions on various topics that are currently available on the site. Members are also allowed to make polls for interesting aerial photos uploaded by other members. The photos with tips and strategies as well as the data of the polls can be used for further analysis and other $\mathrm{R} \& \mathrm{D}$ activities related to aerial images captured from an RC plane.

Anderson and Dickerson, (n.d.) who are electrical engineers with the Kentucky Transportation Cabinet and members of the Intelligent Transportation Systems (ITS) Team, have a slightly different approach. Since they are engineers, they develops their own RC planes based on their experience in flying the planes. They publish a website specifically for RC aerial photography-related matters. Information about the team's aircraft models, samples of aerial photographs taken with such models, and links to other RC photography sites are made available on their websites for further R\&D activities. Figure 3 shows an example of Anderson's self made RC plane and the associated aerial photo captured.

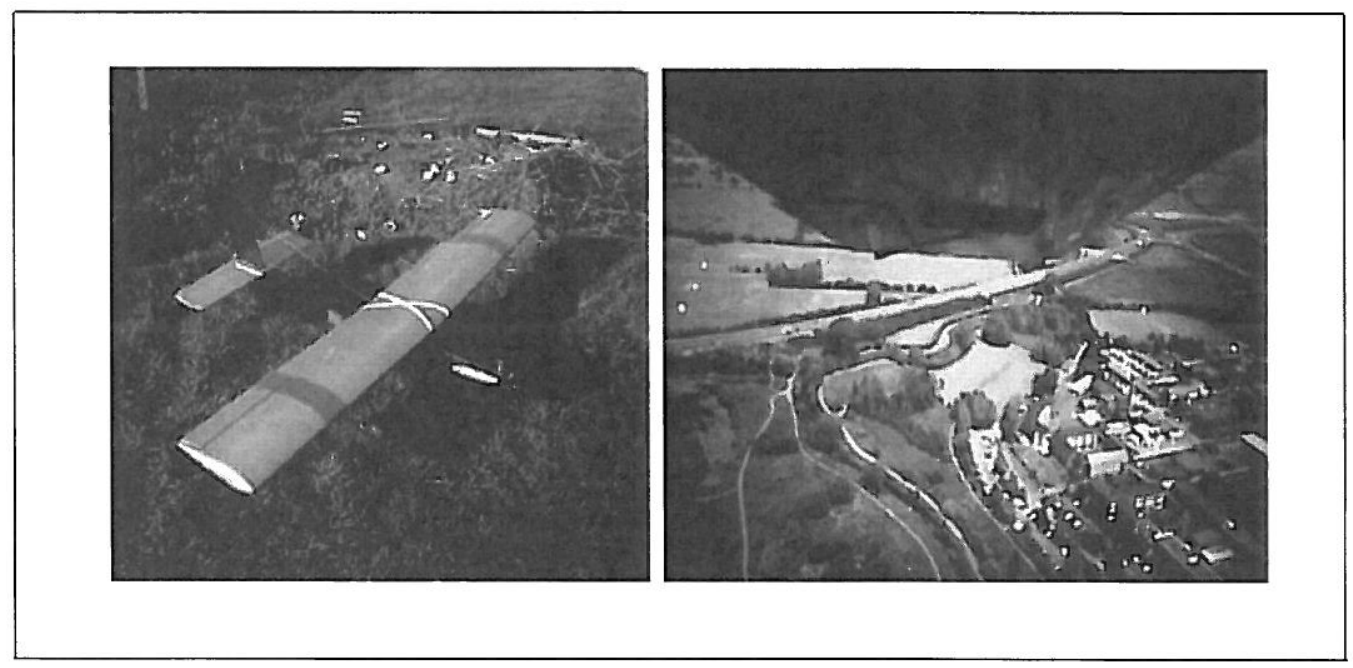

Figure 3: The RC plane built by Anderson and the aerial photo captured (Anderson \& Dickerson, n.d.) 


\section{RC Plane-Related Research}

A handful of research related to aerial photography has already been conducted in other countries. Some of them focus on the imaging technologies and others focus on the vehicle technology used to assist the process of taking aerial photographs.

Work by Gleitsmann and Kappas (2004) focused on imaging technology in an attempt to evaluate a new self contained approach to study high mountain geomorphology using a close range remote sensing method with a low flying light aircraft as a basis for digital oblique aerial photogrammetry. However, unpredictable weather of the study area had caused lot of difficulties to the research team. They have made a conclusion that the method used for getting aerial photos is dangerous to be repeated.

A work carried out by Srinivasan, Latchman, Shea, Wong, and McNair (2004) focused on the vehicle technology. Funded by the Florida Department of Transportation (FDOT), they had built a system called Airborne Traffic Surveillance System (ATSS). ATSS had been succesfully implemented using RC planes, digital video encoding, and transmission of data and multimedia video stream over FDOT's microwave IP networks.

Another work by Herwitz, Leung, Higgins, and Dunagan (2002) had tested new commercial off-the-shelf wireless technology that could improve the performance and cost of line-of-sight telemetry for imaging payloads on RC planes. Their research was sponsored by NASA's unmanned aerial vehicles (UAV) Science Demonstration Programme. The team had also successfully demonstrated the performance of lowcost commercial off-the-shelf components. The payload design was believed to represent a contribution to the continuing development of UAVs as earth platforms for applications such as environmental management, disaster monitoring, and precision agriculture.

\section{THE UUM ATTEMPT}

In Malaysia, this work is first research venturing into RC plane aerial photography product. As an attempt, we started with a small ground area, i.e. the UUM campus area. The images were captured on bright and sunny days because the quality of aerial photography images strictly 
depend on weather conditions (other than the quality of the camera). Another consideration taken into account was the direction of source of light. Thus, in order to produce a series of photographs with the same quality of a certain area, the camera should be facing the same direction and placed on the same orientation.

The series of photographs of the same quality and orientation were then used for creating large scale panoramas or scenes. Such segmented panoramas were referred to as stitched, i.e. the practice of joining multiple conventional photographs with slightly overlapping fields of view so as to create a larger, panoramic image. The panoramic images were stored in a database. Using a computer application, we have developed a container with a suitable engine to display the panoramic image retrieved from the database. The container and the database were integrated to produce the UUM DAS prototype. The prototype was equiped with a direct manipulation feature, enabling users to interact with the prototype by manipulating the display objects, such as icons, buttons, and images using a mouse.

\section{Digital Aerial Scene Development Process}

The Rapid Application Development (RAD) method was used in developing the DAS. Specific steps involved were (1) prototype planning and analysis, (2) data (images)/process analysis and design, (3) DAS prototype development, and (4) DAS prototype tuning and implementation. The following sections specificallly explain the process.

\section{Prototype Planning and Analysis}

Prototype planning and analysis are meant for several purposes: to identify who (people, business, and external application) might need and use the DAS-related application, to discover the operational requirement, to discover control, and security requirements; and, to obtain user requirements. This was done by performing content analysis and a few brainstorming sessions were carried out with experts in RC plane operation. These experts had more than five years experience in flying and repairing RC planes. A briefing session was conducted by the same experts on the control and security matter. A major security issue addressed was the use of highly flammable fuel to fly the RC plane. Accordingly, a few security measures for storing, carrying, refilling, and handling access fuel that should be taken were also informed. 
User requirements were also obtained from the literature. Some justification on why the requirements needed were also acquired using similar method. Other than literature, the requirements were also taken from potential users. They were the university's students, staff, and local people around the university. Discussions were arranged with those potential users to obtain a solid requirement. The requirements, focusing on the features required, obtained were i) entrance interface, ii) pool of image choice, iii) selection of views, iv) ability to put in own scenes, v) scene navigation, vi) zooming in and out, vii) highlights on places of interest, viii) highlights on walkway, ix) scale, $x$ ) area size, $x i)$ description of the area/location, and xii) tooltips of the display widgets.

\section{Data (Images) Analysis and Design}

The purpose of data analysis and design was to properly analyse the user requirements, create preliminary screen flows, capture the aerial scene using the video camera attached to the RC plane, download images from digital video camera, and analyse images to be included in the application. Downloading images from the video camera had been done in real-time. All of those tasks were performed according to the activity diagram as shown in Figure 4.

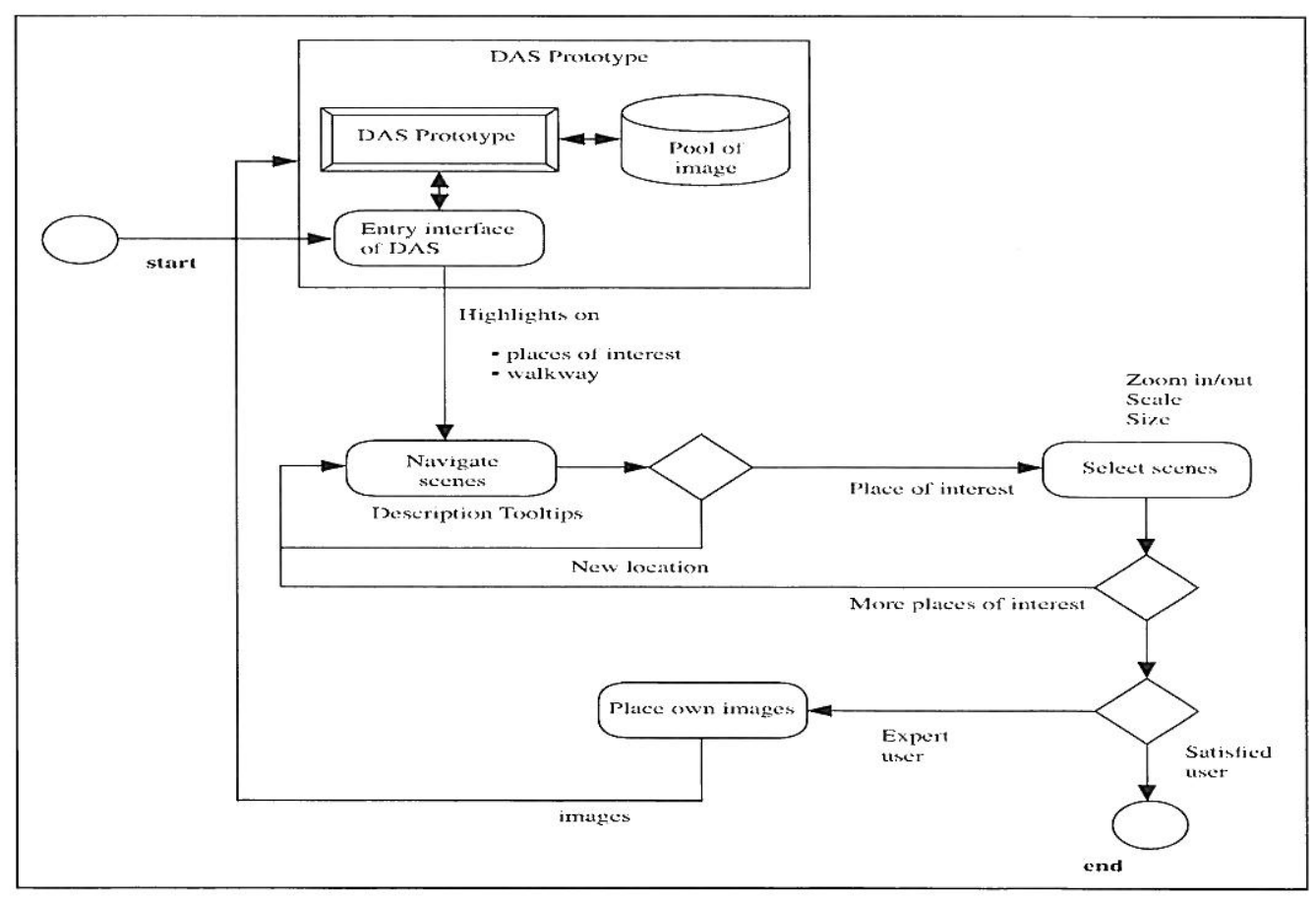

Figure 4: Activity diagram for the DAS prototype

174 IJMS 16 (1), 165-184 (2009) 
As illustrated in the activity diagram in Figure 4, the user requirements could be prioritised. Mock up screen interface and flow were created using an authoring tool called Macromedia Flash MX. Screen sketches were first drafted in the form of story boards. There are three main screens, namely the main page (with campus map), the main menu consisting of hyperlinks to six locations, and a zoom screen displaying selected zoom DAS. The sketches are depicted in Figure 5.

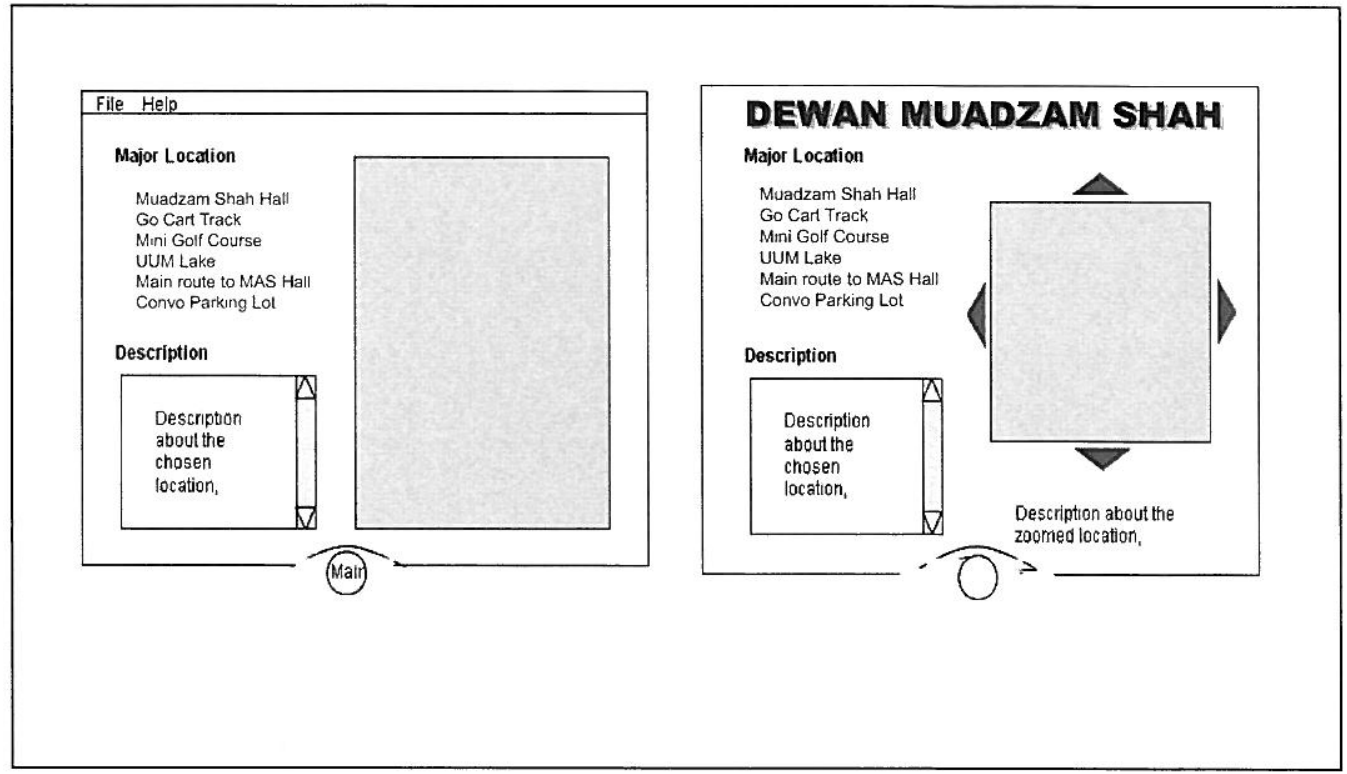
a) Sketch 1: The main menu
b) Sketch 2: The zoomed DAS

Figure 5: The main screens of the DAS prototype

Prototype Development

The objective of developing the prototype was to perform the actual work on generating databases and coding the DAS. This was done by obtaining images, generating the image database, building components for the prototype, reviewing the components, and by performing the integration testing and debugging. The details of these activity are as follows.

The essential tools to capture aerial images were an RC plane, a wireless video camera, a video signal receiver, and a video recorder as shown in Figure 6(i) - (iv). 


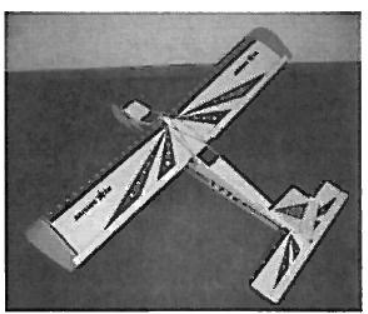

(i) Remote control airplane

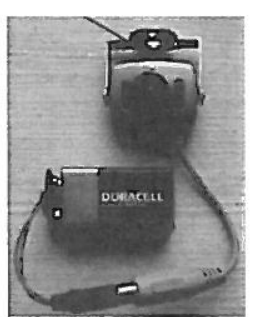

(ii) Wireless video camera
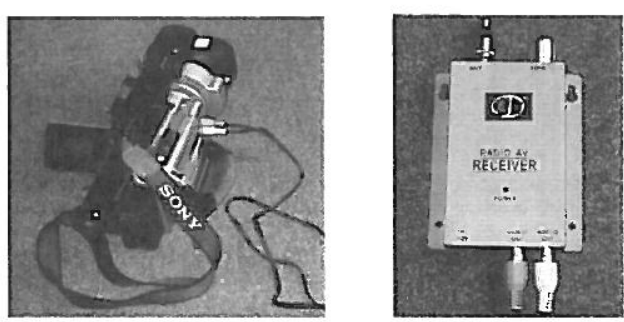

(iii) Video recorder

(iv) Video signal receiver

Figure 6: Tools to capture aerial images

The RC plane was well equipped with gasoline engine, servos, speed control, and signal receiver. It had a unique remote control frequency which is $81.40 \mathrm{MHz}$. To start the engine, one must attach an electric gun or glow starter (Figure 7) to the ignition part and then turn the propeller anti-clockwise.

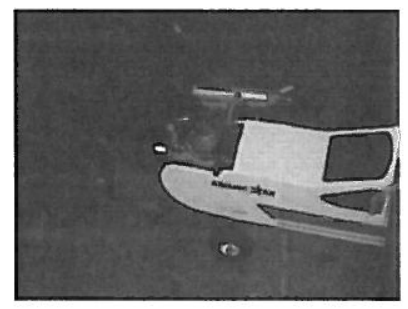

(i) Gasoline engine

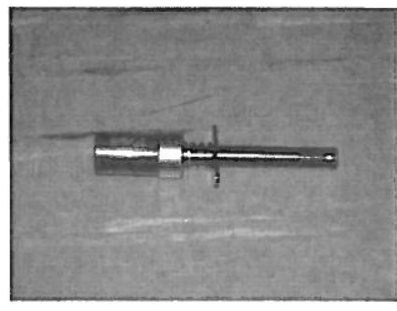

(ii) Engine starter (glow starter)

Figure 7: RC plane setup

The camera was then attached firmly under the fuselage as shown in Figure 8. It was powered by 9.0 Volt dry cell. In order to get better video signal transmission, the antenna was modified by extending it with copper wire.

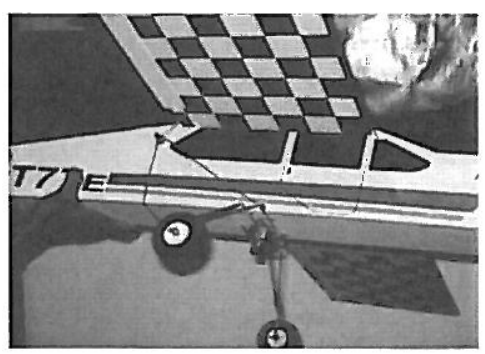

(i) Camera attached tied underneath the plane

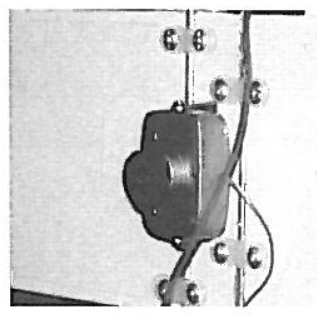

(ii) Camera

Figure 8: The camera setup

176 IJMS 16 (1), 165-184 (2009) 176 
Next the video signal receiver and video recorder were set up. The video signal receiver was powered by a dry cell battery. In order to get better receiving signal quality, the original antenna was extended using a wire and attached to a remote antenna. In this study, a digital video camera was used as the video recorder. The video camera was connected to the receiver module using a signal cable. The video camera was set in recording mode to record the transmitted video from the RC plane. Figure 9 shows the the setting for the said receiver and recorder.

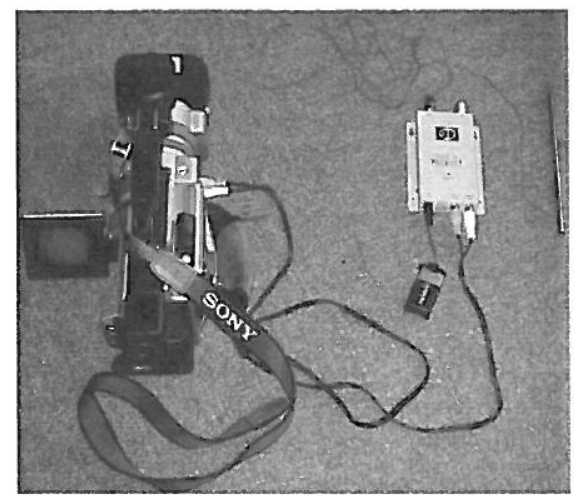

Figure 9: Video camera connected to the receiver

The process for capturing the aerial view began with identifying appropriate areas for capture. Locations that had some free space or runway to allow the take off and landing of the plane safely were chosen. The RC plane, after take-off, flown to was about 100 - 150 metres above the target location. Formulas obtained from Akimov and Vorob'ev (2001) to compute the RC plane position angles during maneuvers were used. The wireless video camera captured the scene and transmitted the signals back to the receiver. Subsequently, the video recorder had recorded the video signals onto a mini DV tape. This process is illustrated in Figure 10.

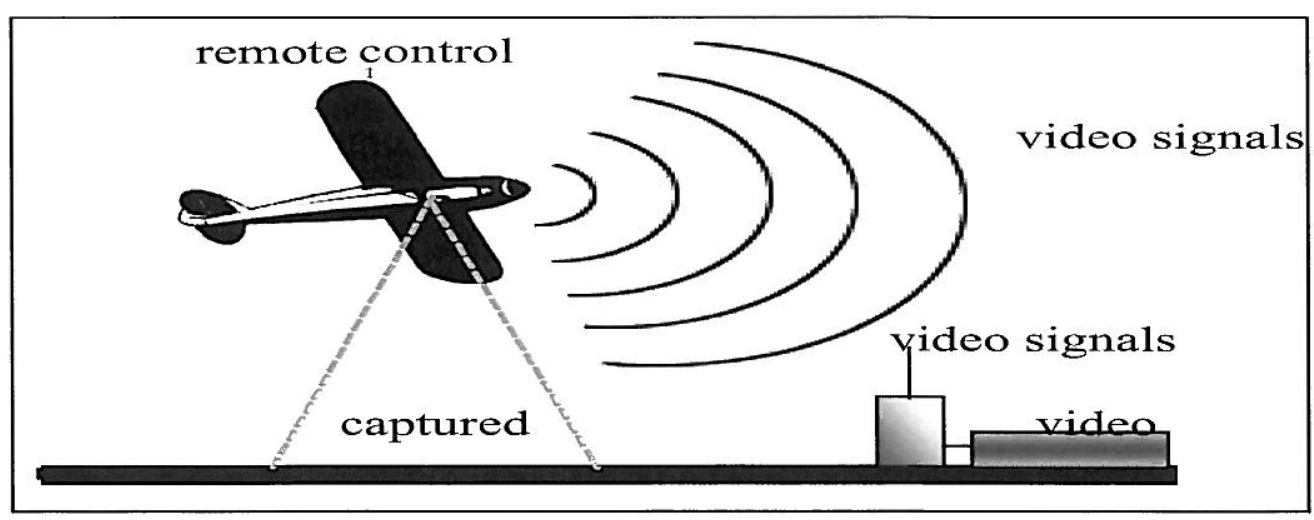

Figure 10: Aerial scene capturing process

IJMS 16 (1), 165-184 (2009) 
The captured video sequence were stored in a DAT tape. Using the Firewire interface, the sequence was transmitted to the computer hard disk using Ulead Video Studio application software. This step is demonstarted in Figure 11.

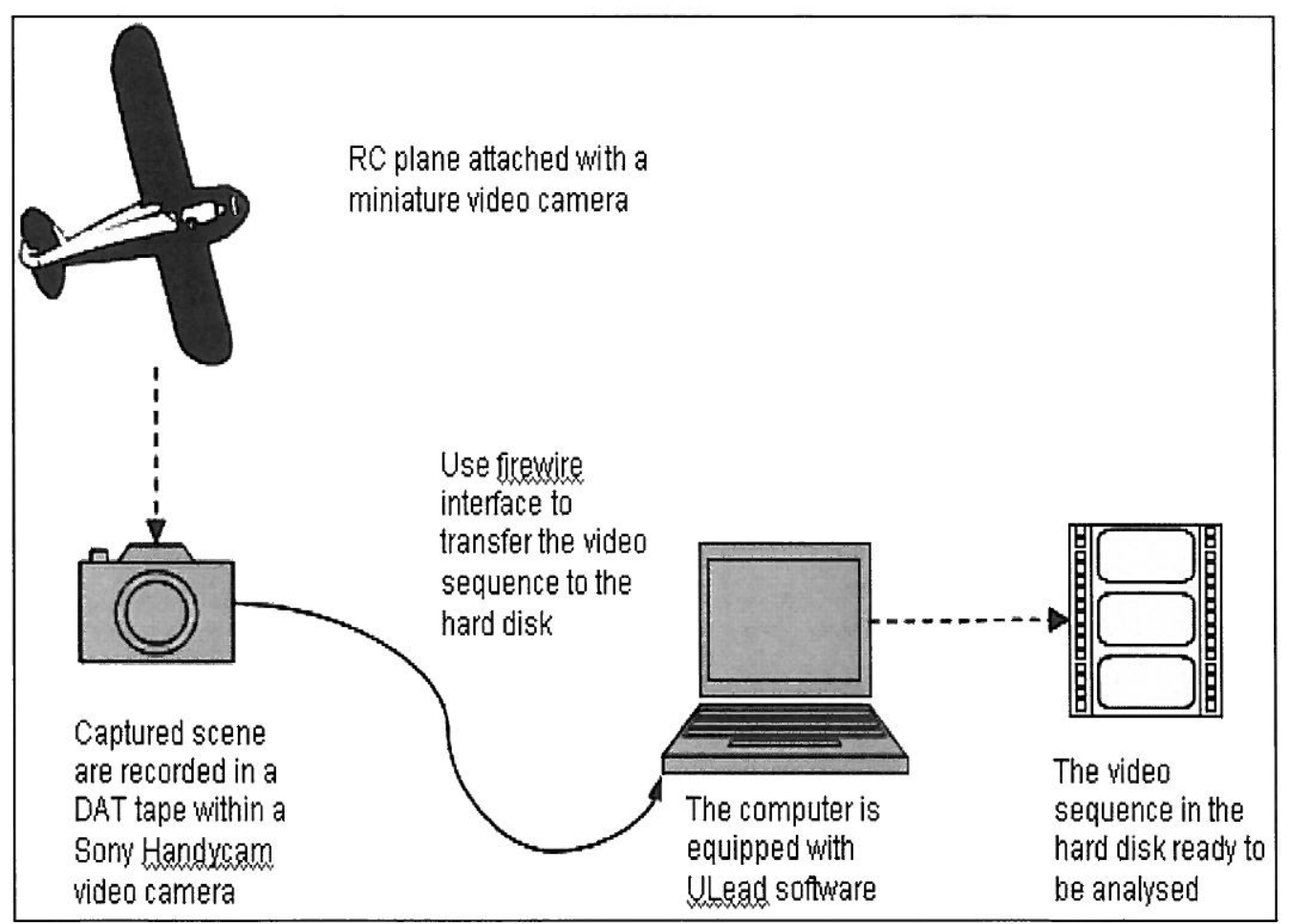

Figure 11: Steps in downloading images to the computer

We analysed the images to be included in the application by firstly, removing the audio track from the video sequence. Then, we carried out a manual analysis of the video frames in order to choose the most appropriate frames for the DAS. Choices were made based on the following criteria. Firtsly, the frames selected were of the best photo quality. Secondly, the photos were taken from similar altitude (or at least the difference in height is not obvious). Thirdly, the amount of light in the chosen photos, in terms of brightness and contrast, were the same. This is particularly important in photos taken by RC planes because when the plane changes its direction, the lighting angle (which solely depends on sunlight) also changes. Finally, the photos chosen were those of significant areas on campus. Figure 12 depicts eight samples of the frames captured from our video sequence. 

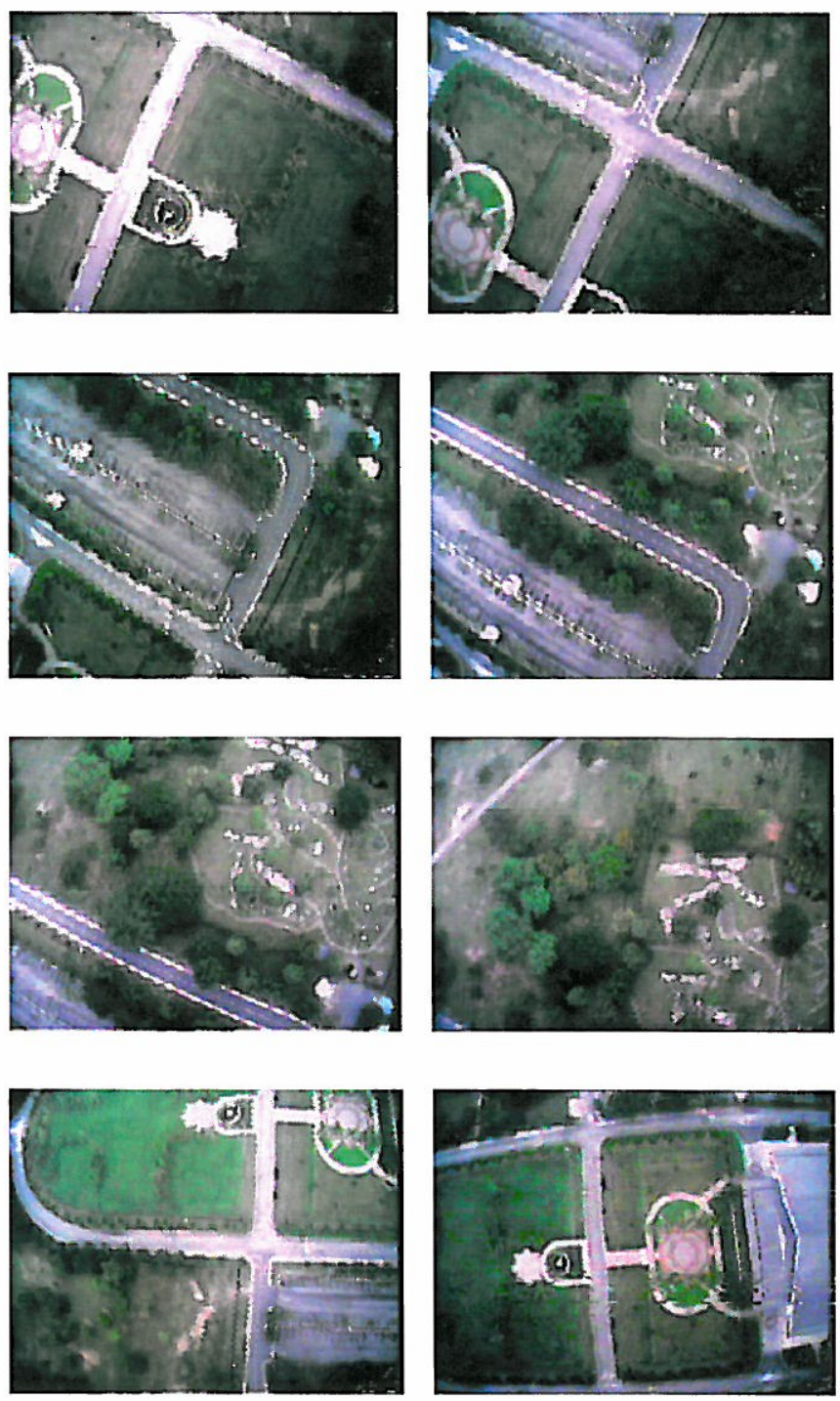

Figure 12: Frames captured from a video sequence

We have generated the image database by analysing frames and extracting them as separate photographs, These steps were done manually. Later, we embarked on the virtual scene development by firstly touching up the selected images using Adobe Photoshop. This was to ensure that the colour coordination, brightness as well as the size of the images were suitable. Once done, the images were joined one by one also with the use of Adobe Photoshop. This process was very much similar to matching up a jigsaw puzzle. Figure 13 gives a picture of having all images joined. Obviously, a panoramic view from the top is now formed. 


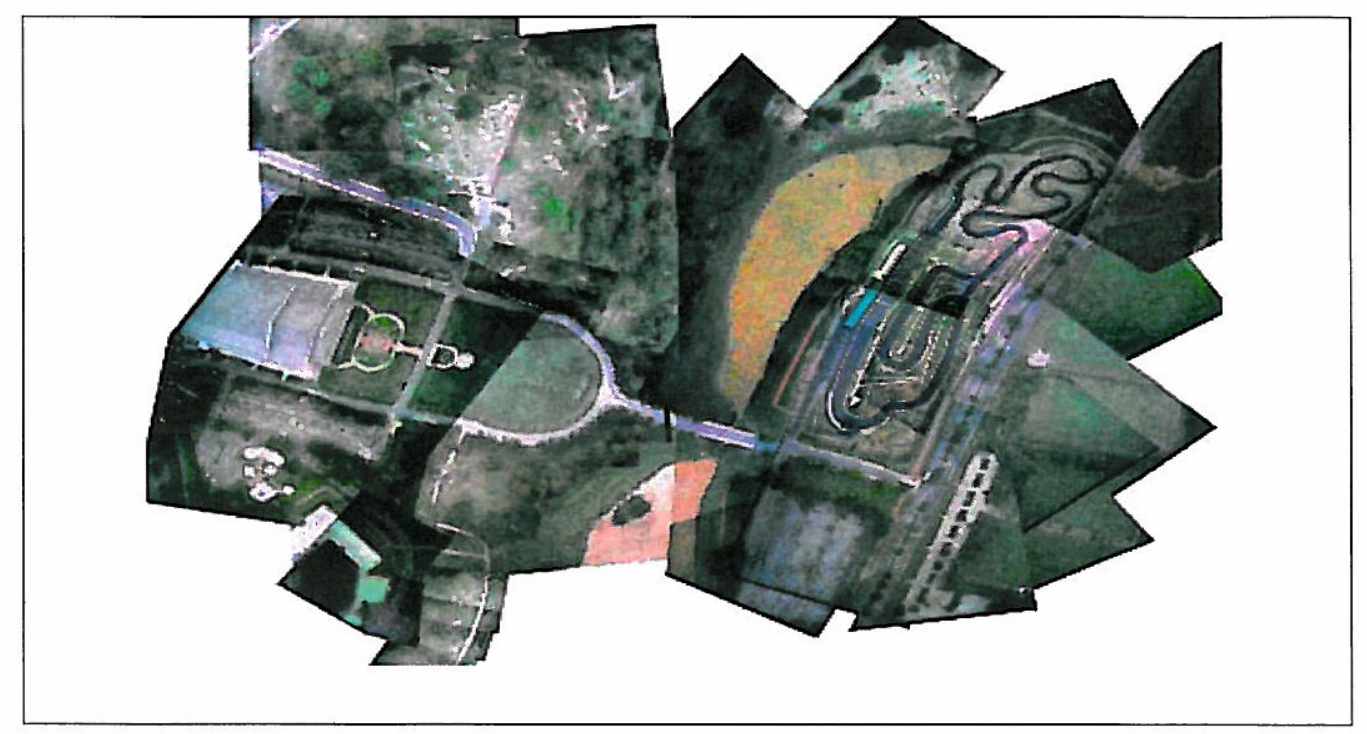

Figure 13: Combination of the frames captured

Six main locations were highlighted in the map, namely i) convocation parking lot (this is the main parking lot for visitors and students during UUM convocations), ii) the go-kart track (the latest international standard facility available on campus), iii) main road to Muadzam Shah Hall (the well-maintained grand hall with professionally designed landscape), iv) the campus mini golf course (one of the most difficult courses available in the Northern region), v) Muadzam Shah Hall (the grand hall for any auspicious functions held inside campus), and vi) UUM Lake (a point for out-door water activity).

Having the image database and the panoramic view ready, we proceeded with component building and grouping. The user requirements were used as basis for determining the total number of components to be developed. Eleven components have been identified, namely i) general info, ii) UUM map, iii) hyperlink to the selected scene, iv) links to other scenes which are not viewed at the moment, v) description of the displayed scene, vi) the DAS view, vii) 12 active selections in the DAS view, viii) miniature map of (ii), ix) zoom-in two levels with four navigation buttons (south, north, west, east), $\mathrm{x}$ ) description/info of the zoomed area, and xi) zoom east/west/south/north. These components are then grouped according to the screen sketches as depicted in Figure 5 earlier.

Using the 11 components, we then designed the navigation structure as simplified in the navigation map shown in Figure 14. The objective 
of designing such a navigation map was to logically structure each function of the DAS in line with the user requirements. Each of the components was reviewed in terms of design and user interaction suitability. Each component was tested for its behaviour to ensure that each time when it was activated, it would behave accordingly. This was done before all components were integrated and tested together. The overall user interface was designed according to the general humancomputer interaction ( $\mathrm{HCI}$ ) principles (colour, font, layout, interaction, arrangement, and behaviour of components). The whole prototype was then tested as one unit, for its overall form, content, and behaviour.

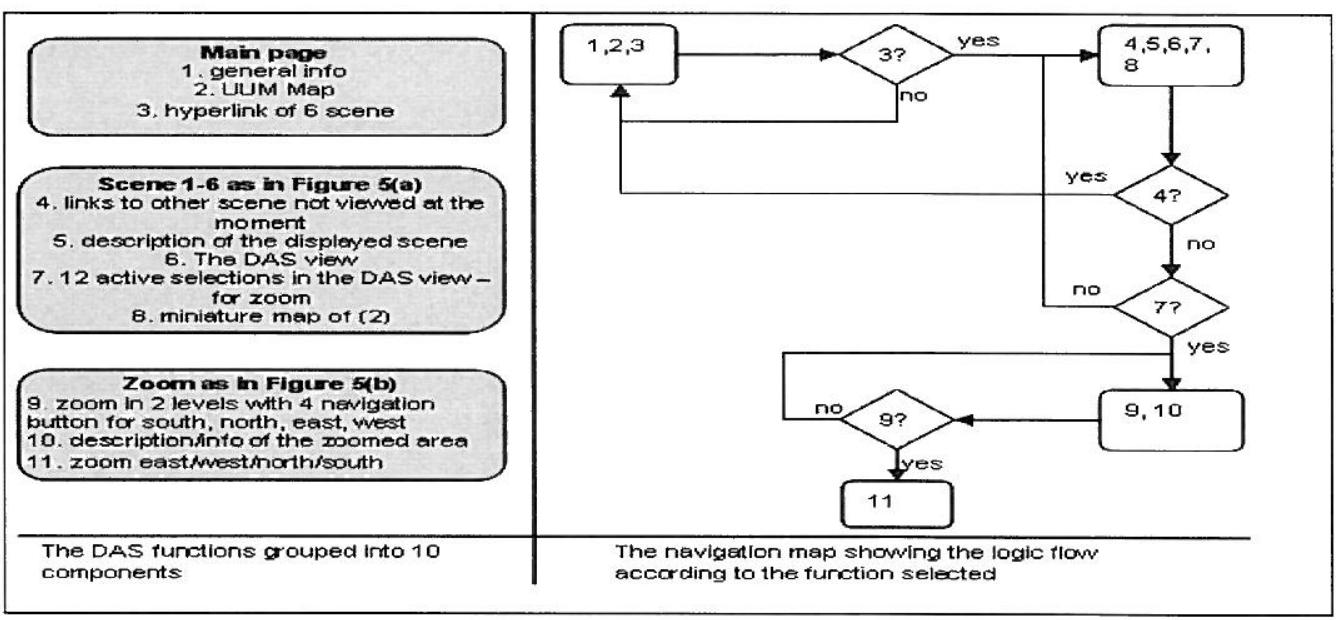

Figure 14: DAS components and navigation map

\subsubsection{The Prototype Tuning}

The prototype was then fine-tuned by converting the images in the database into JPEG format, enabling faster preview of images without unnecessary delay. This step was done to enable DAS to run faster, especially when displaying selected images.

The user interface of the prototype was also fine-tuned. Actual users were invited for this process. Their input and feedback were gathered during the viewing sessions. They were given the opportunity to testrun the DAS prototype, and later provide feedback on various aspects of the user interface, such as the layout, colour, navigational aids, help, and on the interaction design in general. Although the DAS display design adhered to the principles of $\mathrm{HCI}$, we still had to consider the direct user comments, critiques, and suggestions. However, the alterations were made without sacrificing the underlying principles of HCI.

IJMS 16 (1), 165-184 (2009) 


\section{RESULTING PROTOTYPE}

Figure 14 shows screen shots of the finalised DAS prototype, i.e. its main page and one example scene, delivered with its 11 intended features as considered necessary in the requirements.

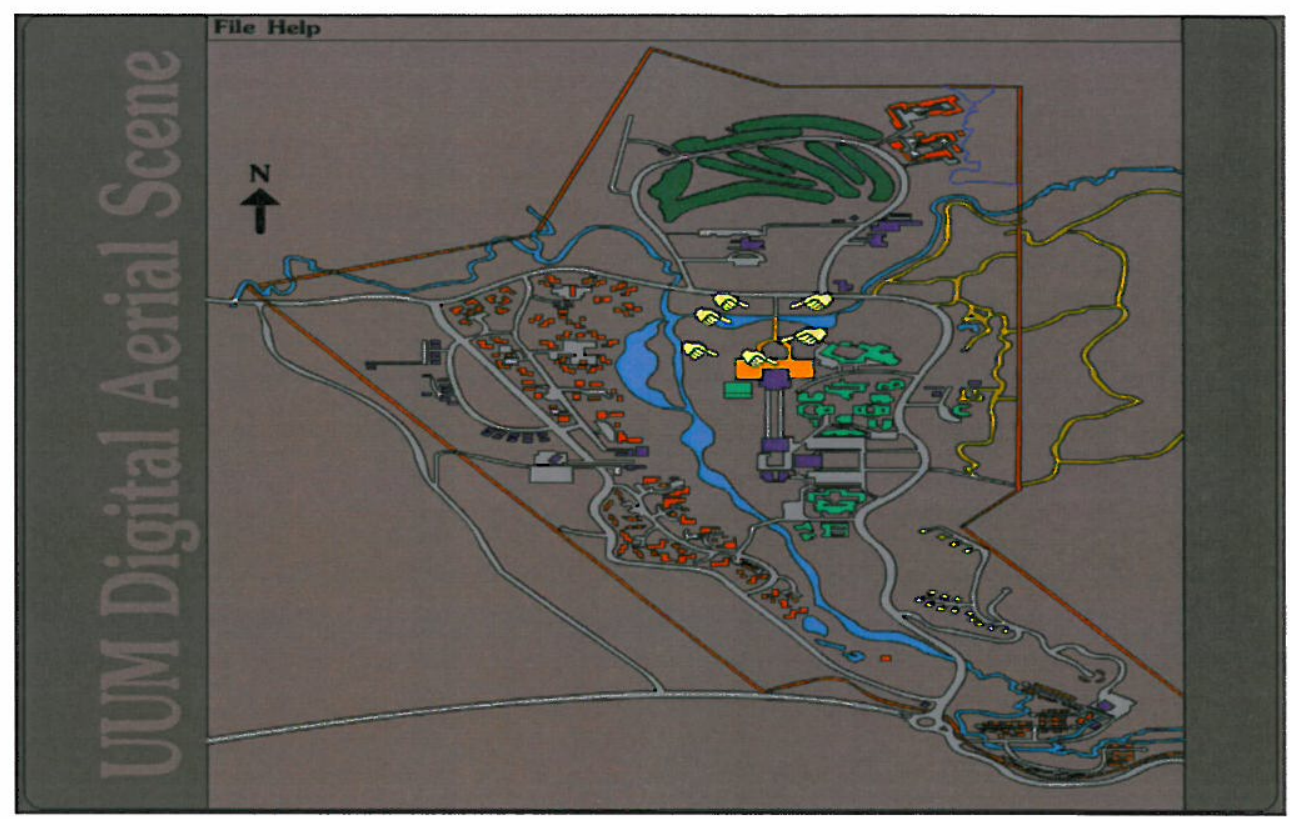

(i) Main page

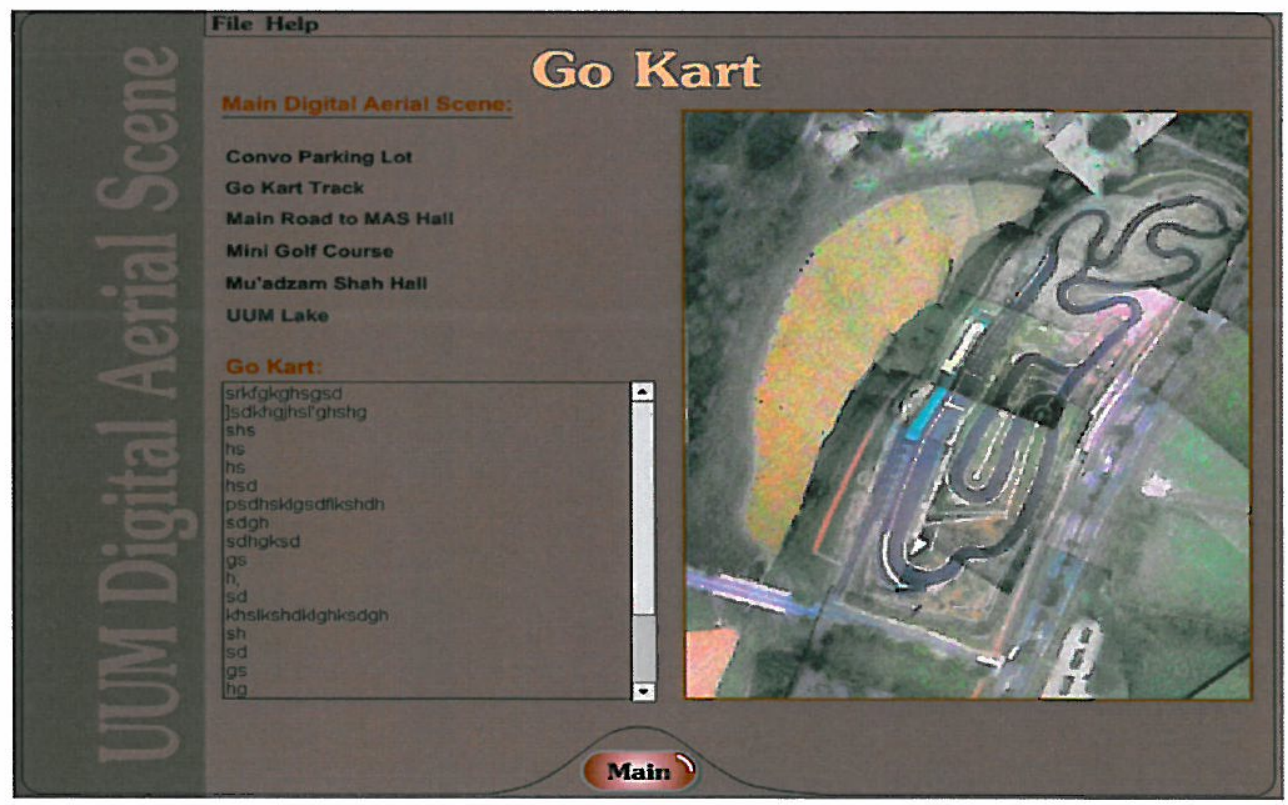

(ii) Go Kart Track

182 IJMS 16 (1), 165-184 (2009) 


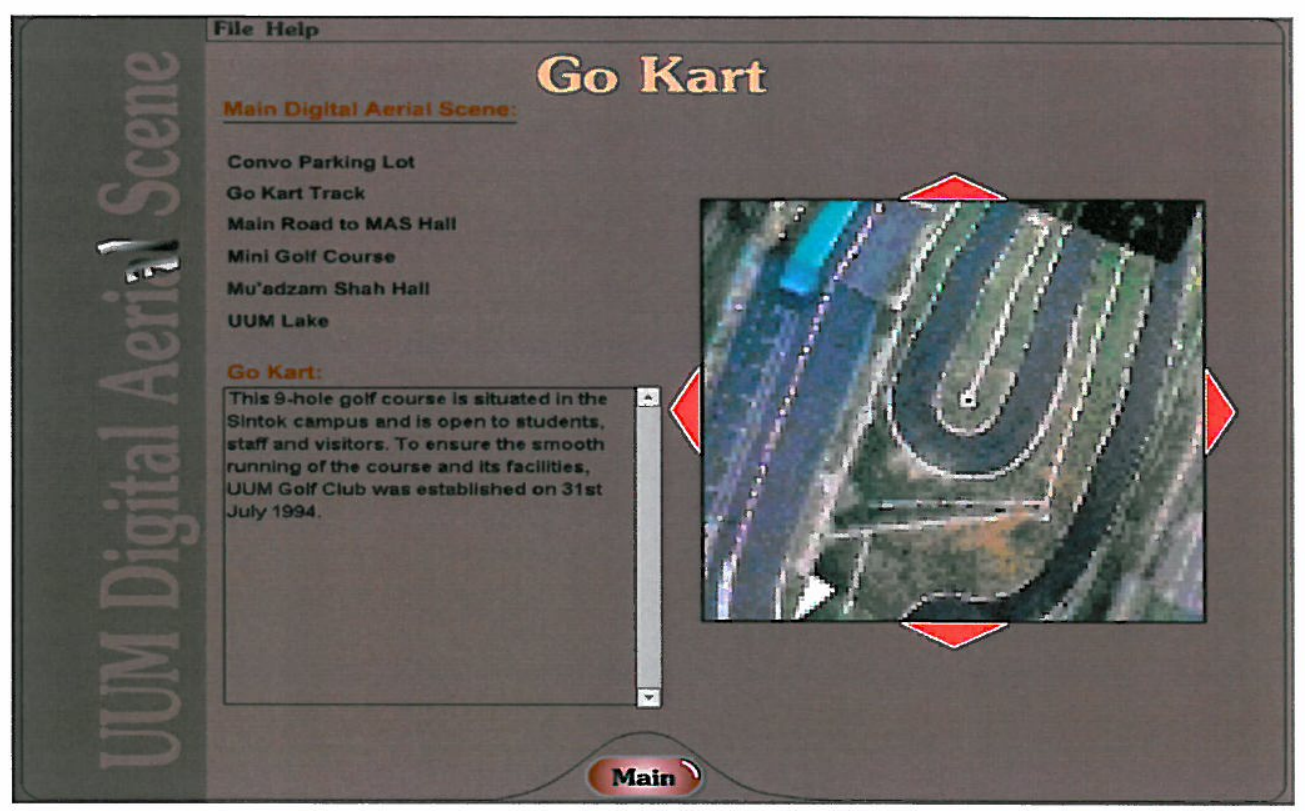

(iii) Zoomed Go Kart Track

Figure 14: Screen shots of DAS application prototype

\section{CONCLUSION AND RECOMMENDATION}

There are now three ways to capture aerial photos: via the dreadfully expensive satellites, via a noisy and costly real manned airplanes, and through the use of cheap and easy to manage unmanned RC airplanes. Realising that the latter has yet to be explored, this study was carried out and managed to achieve the objective in generating a DAS prototype, which provides digital aerial scenes for selected locations within UUM.

For future work, it is recommend that other researchers should use this approach of photography for the benefit of other fields such as farming and plantation, cartography, archaeology, and land survey. It is also recommended that similar work on aerial photography using $\mathrm{RC}$ planes with more powerful camera, better resolution, and wider viewing angle should be performed.

\section{REFERENCES}

Akimov, A.N., \& Vorob'ev, V.V. (2001). A method and algorithms for veering a flying apparatus from the spatial constarint surface. Journal of Automation and Remote Control, 62(7), 1042-1048. 
Anderson, G.W., \& Dickerson, B. (n.d). RC aerial photography. Retrieved September 16, 2006, from http://www.geocities.com/ capecanaveral/ 7376/index.html

Gleitsmann, L., \&Kappas, M. (2004). Digitalmulti-image photogrammetry combined with oblique aerial photography enables glacier monitoring survey flights below clouds in Alaska. Proceedings of the Geoscience and Remote Sensing Symposium (GARSS), 2004 IEEE International, 2, 1148-1151.

Hemphill, J.J. (2006). Pigeon Aerial Photographs. Retrieved October 12, 2006, from http://www.geog.ucsb.edu/ jeff/115a/history/ pigeonremotesensing.html

Herwitz, S.R., Leung, J.G., Higgins, R.G., \& Dunagan, S.E. (2002). Remote command-and-control of imaging payloads using commercial off-the-shelf technology. Proceedings of the Geoscience and Remote Sensing Symposium (GARSS), IEEE International, 5, 2726-2728.

McFayden, A. (2005). Better digital photography: Aerial photography with airplanes. Retrieved October 2, 2006, from http:// betterdigitalphotography.blogspot.com/2005/02/aerialphotography-with-rc-airplanes.html.

RCGroups.com (2006). RCGroups.com: The ABCs of radio control - Aircrafts, boats and cars. Retrieved October 2, 2006 from http://www.rcgroups .com/forums/index.php.

ShredAir (2005). ShredAir: Radio control flying products and aerial photography. Retrieved October 2, 2006, from http://www.shredair .com/home.html.

Srinivasan, S., Latchman, H., Shea, J., Wong, T., \& McNair, J. (2004). Airborne traffic surveillance systems - Video surveillance of highway traffic. Proceedings of the ACM 2nd International workshop on Video Surveillance and Sensor Networks, 131 - 135.

the-lightbox. (n.d.). The Lightbox: Simon Kirwan. Retrieved October 12, 2006, from http://www.the-lightbox.com/

Veliz, D. (2006). Aerial pictures by Derick Veliz. Retrieved October 9, 2006, from http://groups.msn.com/AerialPicturesbyDerickVeliz/ aerialphotography.msnw.

184 IJMS 16 (1), 165-184 (2009) 